University of Nebraska - Lincoln

DigitalCommons@University of Nebraska - Lincoln

Faculty Publications: Agricultural Leadership, Education \& Communication Department
Agricultural Leadership, Education \& Communication Department

October 2004

\title{
Does Sex of Dyad Members Really Matter? A Review of Leader-Member Exchange
}

Brent J. Goertzen

Fort Hays State University, bgoertze@fhsu.edu

Susan Fritz

University of Nebraska - Lincoln, sfritz1@unl.edu

Follow this and additional works at: https://digitalcommons.unl.edu/aglecfacpub

Part of the Other Public Affairs, Public Policy and Public Administration Commons

Goertzen, Brent J. and Fritz, Susan, "Does Sex of Dyad Members Really Matter?

A Review of Leader-Member Exchange" (2004). Faculty Publications: Agricultural Leadership, Education \& Communication Department. 26.

https://digitalcommons.unl.edu/aglecfacpub/26

This Article is brought to you for free and open access by the Agricultural Leadership, Education \& Communication Department at DigitalCommons@University of Nebraska - Lincoln. It has been accepted for inclusion in Faculty Publications: Agricultural Leadership, Education \& Communication Department by an authorized administrator of DigitalCommons@University of Nebraska - Lincoln. 


\title{
Does Sex of Dyad Members Really Matter? A Review of Leader-Member Exchange
}

\author{
Brent J. Goertzen \\ Assistant Professor \\ Department of Leadership Studies \\ Fort Hays State University \\ Hays, KS 67601 \\ bgoertze@fhsu.edu \\ Susan M. Fritz \\ Head and Professor \\ Department of Agricultural Leadership, Education and Communication \\ Lincoln NE 68583-0709 \\ smfritz1@unl.edu
}

\begin{abstract}
Leader-member exchange (LMX) generally refers to the leadership process centered on the interactions between leaders and direct reports. The basic premise of high quality leader-member exchange relationships holds that direct reports gain tremendous benefits through these partnerships. LMX is perhaps the most commonly researched theory of leadership. However, few studies have specifically examined the role of dyad members' sex as a predictor of quality LMX. Several studies investigating the role of dyad members' sex and quality LMX examined the effect of sex in an aggregated variable, demographic similarity, which often included other demographic characteristics such as age, education level and race, yielding mixed results. This article's purpose is to (a) review the evolution of leader-member exchange theory, (b) examine literature regarding potential effects of sex of dyad members on quality leader-member exchanges, and (c) discuss implications and future research concerning the role of dyad members' sex and leader-member exchanges.
\end{abstract}

\section{Introduction}

Quality leader-member exchange (LMX) theory is perhaps the most widely researched theory of leadership. Leader-member exchange is a perspective of the leadership process that focuses on the quality of interactions between the leaders and direct reports. Leader-member exchange theory asserts that managers do not treat or evaluate their direct reports in the same way (Graen, 1976). These high quality relationships are characterized by dyad members possessing strong mutual affection based on interpersonal attraction, expressing public support for the goals of the other member, and perceiving professional respect for one another (Liden 
\& Maslyn, 1998). Direct reports within relationships characterized by high quality exchanges receive disproportionate attention from managers, receive higher performance evaluations, report lower turnover rates, and experience greater satisfaction with their managers (Gerstner \& Day, 1997). Research has indicated that quality of leader-member exchanges has impacted direct reports' workplace experiences (Vecchio \& Gobdel, 1984). It follows that the work place experiences of male and female employees will also be affected by the quality of leadermember exchanges (Varma \& Stroh, 2001). Despite extensive research regarding the notion of quality leader-member exchanges, comparatively little research has examined the impact of sex of dyad members on the quality of leader-member exchanges.

This article explores literature in which sex of dyad members has been examined within the context of LMX theory. The primary purpose for this review is twofold: (a) to examine what is currently known regarding the impact of sex of dyad members and leader-member exchanges and (b) to develop recommendations for future research regarding these two constructs.

\section{LMX Theory: A Review}

Based on their observations and review of the literature, Graen and Uhl-Bien (1995) described a taxonomy of leadership theory. They claimed research exploring the concept of leadership is incomplete if it focuses solely on the leader (e.g., characteristics, dispositions, traits or behaviors). Rather, the construct of leadership encompasses three domains: the leader, the follower and the relationship. As can be inferred from the label of each of the domains, the leader domain primarily focuses on the leader (e.g., characteristics, traits, behavior, personality, etc); the follower domain concentrates on the follower (e.g., follower traits, characteristics, behavior, attitudes, etc); and the relationship domain concerns the dyadic relationship between the leader and the follower (e.g., trust, respect, mutual obligation). Research supports three domains of leadership within organizations. The three domains of leadership in combination accounted for significant variation in leadership outcomes such as innovative behavior (Basu, 1991). Though studies could focus on a single domain of leadership, studies exploring multiple domains of leadership might offer rich insight into the dynamics of leadership.

Currently, LMX theory is defined as a relationship-based approach to leadership research (Graen \& Uhl-Bien, 1991). The theory's premise holds that effective leadership processes occur when leaders and followers develop and sustain mutual relationships and, therefore, gain access to tremendous benefits brought by these "partnerships." Leader-member exchange is perhaps the most widely researched theory in leadership over the past 30 years.

Schriesheim, Castro, and Cogliser (1999) developed a comprehensive overview of the nearly 150 published articles since the concept was originally introduced in 
1972 (Graen, Dansereau, \& Minami, 1972). Initially labeled "Vertical Dyad Linkage” (Dansereau, Graen, \& Haga, 1975), the theory subsequently evolved into its current label of LMX theory. This relationship-based approach to leadership theory has advanced through four stages (Graen \& Uhl-Bien, 1995).

The first stage of LMX evolution began as an initial investigation into the leadermember exchange issues in the context of socialization (Graen, Orris, \& Johnson, 1973) and Vertical Dyad Linkage (Dansereau, et al., 1975). Studies found that managers developed differentiated relationships with direct reports within their organizations. At one extreme managers reported high quality relationships ("ingroups") characterized by high mutual respect, trust, and obligation. At the other end of the continuum they reported low quality relationships ("out-groups") characterized by relatively low degrees of mutual respect, trust, and obligation (Dansereau, et al., 1975).

The second evolutionary stage of LMX theory addressed its relationship with organizational outcomes (Graen \& Uhl-Bien, 1995). In addition to investigating the relationship between LMX and organizational outcomes - such as performance, turnover, job satisfaction, organizational commitment, and performance appraisal (Gerstner \& Day, 1997) - research during this stage of development also evaluated the characteristics of the dyadic relationships. Several of these characteristics included dyadic-role making process (e.g., Graen, et al., 1973), communication frequency (e.g., Schiemann, \& Graen, 1984), and leadermember value agreement (e.g., Graen \& Schiemann, 1978).

Stage three in the evolution of LMX focused more on the processes for developing effective leadership relationships (Graen \& Uhl-Bien, 1995). In other words, leadership was seen as a partnership between the leader and the follower. Rather than treating some employees more favorably than others, this stage of LMX attempted to assist managers in providing access to LMX processes for all employees. Offering LMX to all members provided two important benefits for this partnership access: “1) the LMX process may be perceived as more equitable $\ldots$ 2) the potential for more high-quality relationship development would increase the potential for more effective leadership and expanded organizational capability” (p. 229).

This partnership development process is analogous to a life cycle comprised of three primary phases. The life cycle begins with the "stranger phase" wherein individuals first come together as strangers participating in roles within an organization. The second phase, "acquaintance stage," is characterized as increased social exchanges between the members. "Mature partnership," the final phase, is characterized as a highly developed relationship with exchanges reciprocated in kind.

The fourth stage in the development of LMX theory concentrates on a systemslevel perspective "mapping” the leadership structure by the formally defined roles 
of organizational members (Graen \& Uhl-Bien, 1995). Currently, this area of LMX theory has been unexplored, but it has been suggested that it offers great possibilities for future research (Graen \& Uhl-Bien, 1995).

Leader-member exchange is perhaps the most widely researched leadership theory, however, there is limited consensus as to the appropriate measurement of the construct. Schriesheim et al., (1999) noted of research published in the 1980s that 16 different measures were used to assess the quality of leader-member relationships. The LMX-7 is a seven-item scale assessing leader-member exchanges and includes items such as "I usually know where I stand with my employee," "My employee understands my problems and needs," and "My employee would use his/her power to help me solve problems in my work" (Scandura \& Graen, 1984). The LMX-7 scale is the most widely used measure of leader-member exchange (Schriesheim, et al., 1999).

Many scales assessed LMX as a one dimensional construct. However, Liden and Maslyn (1998) developed the LMX-MDM to assess leader-member exchanges as a multi-dimensional construct. The dimensions of the LMX-MDM include affect, loyalty, contribution, and professional respect. Limited research has assessed LMX with the LMX-MDM, nevertheless, the measure holds promise for further understanding the complex phenomena of quality leader-member exchanges.

\section{Antecedents of LMX}

Leader-member exchange has been researched from a variety of perspectives. Though quality of LMX is frequently examined as a predictor of organizational outcome variables such as performance (e.g., Graen, Novak, \& Sommerkamp, 1982), job satisfaction (e.g., Graen, et al., 1982), organizational commitment (e.g., Seers \& Graen, 1984) and organizational citizenship behavior (e.g., Scandura, Graen, \& Novak, 1986), research has also addressed determinants, or antecedents, of LMX.

Extensive research has investigated various predictors in the quality of LMX. Numerous studies investigating predictors of quality leader-member exchanges examined demographic, attitude, and perceived similarities between both participants in the leader-member dyads. For instance, attitudinal similarity (Phillips \& Bedeian, 1994), perceived similarity (Murphy \& Ensher, 1999), and demographic similarity (e.g., Liden, Wayne, \& Stilwell, 1993) all predicted quality leader-member exchanges. However, sex similarity of dyad members appears to be less clear. For instance, Bauer and Green (1996) indicated sex sameness of dyad members did not predict quality leader-member exchanges, yet sex dissimilarity was related to lower quality leader-member exchanges (Green, Anderson, \& Shivers, 1996).

There is a body of literature which has examined the role of various leader characteristics and perceptions as predicting quality leader-member exchanges. 
For instance, leaders' reported leadership efficacy and optimism did not predict quality LMX (Murphy \& Ensher, 1999). However, leaders' reports of members’ attributes were significantly related to "in-group” status (Heneman, Greenberger, \& Anonyuo, 1989). In other words, leaders reporting high quality exchanges with direct reports were more likely to attribute effective performance of direct reports to internal attributes such as effort and ability. These internal attributions were significantly higher for "out-group” members when performance was ineffective. The quality of exchanges affects the formation of attributions by a leader.

Other research investigating predictors of leader-member exchanges have examined the role of various member characteristics, attitudes, and behaviors. Several member characteristics positively associated with LMX include extroversion (e.g., Phillips \& Bedeian, 1994), internal locus of control (Kinicki \& Vecchio, 1994), liking of the leader (Liden, et al., 1993), and in-role behaviors (Basu \& Green, 1995). Also, member ingratiatory behaviors are theorized to be associated with leader-member exchanges (Wayne, Liden, \& Sparrowe, 1994). Further, member negative affectivity was inversely related to leader-member exchange (Hui, Law, \& Chen, 1999).

Additionally, limited research has investigated organizational contexts as predicting quality leader-member exchanges. For instance, Kinicki and Vecchio (1994) indicated that time pressure may have a stimulating effect on quality LMX. However, Green, et al. (1996) revealed unit size and workload have inverse relationships with the quality of LMX.

Within the area of leadership research exploring quality of leader-member exchanges there remains a construct which has received attention to varying degrees. Several empirical studies directly examine the role of sex of dyad members in the development of quality leader-member exchanges, while other research appears to treat sex of dyad members as an ancillary, or a variable to control for in the research. The following sections will describe these empirical studies and attempt to bridge together current knowledge regarding the role of sex of dyad members and quality leader-member exchanges.

\section{Theoretical Basis of Sex of Dyad Members and LMX}

Wayne, et al. (1994) developed a theoretical framework examining the potential role of sex of dyad members and ingratiatory influence behaviors in the development of quality leader-member exchanges. Similar to other research examining the effects of sex of dyad members, or other demographic similarity constructs on various outcomes within dyads (e.g., Tsui \& O’Reilly, 1989), Wayne et al. (1994) posited that members with same-sex leaders would be more likely to develop high quality exchanges than members with opposite-sex leaders. The theory further asserted that females (males) who successfully use ingratiation tactics with male (female) superiors would likely develop higher quality leader- 
member exchanges than females (males) who do not successfully make use of ingratiation tactics.

Other propositions suggest that gender stereotypes may play a role in the development of quality leader-member exchanges, specifically with regard to jobrelated information. For instance, the less job-related information that is available to a leader or member, the more likely gender stereotypes would influence the development of quality leader-member exchanges. Moreover, it is proposed that female leaders will be rated lower on quality of leader-member exchanges because of a perceived lack of access to resources that may enhance the quality LMX. This will be particularly evident if women occupy traditionally masculine positions.

Nonetheless, the propositions offered in the theoretical framework remain just that, theory. The review of LMX literature has not yielded empirical evidence confirming or refuting these propositions. Though research has not examined all of these particular propositions, other empirical literature regarding quality leadermember exchanges has investigated the potential effects of same-sex and mixedsex dyads on the development of quality leader-member exchanges.

\section{Demographic Similarities/Differences}

There has been substantial research conducted on the demographic similarities and differences between managers and direct reports in the dyadic relationships as antecedents to quality leader-member exchanges. Studies exploring possible antecedents of LMX frequently attempt to account for demographic factors, including sex of dyad members (Larwood \& Blackmore, 1978; Duchon, Green, \& Taber, 1986; Liden, et al., 1993; Basu \& Green, 1995).

Larwood and Blackmore (1978) recorded the behavior of 60 management students who were asked to recruit volunteers to participate in a research project. The researchers operationalized acquaintances as in-groups. It was hypothesized that more acquaintances of the subject's own sex than of opposite sex would be asked to volunteer, yet among the people asked to volunteer who were not previously known, no significant differences would be found. The data indicated the respondents who were previously known by subjects were more likely to be asked to participate in the challenging or remunerative tasks. Put differently, members of in-groups with whom the role exchange process was carried out were predominately of the same sex as the subject. That is, females tended to recruit females and males tended to ask males to volunteer. This bias was particularly strong under more favorable task conditions or the best situations.

Similarly, Duchon, et al. (1986) examined sex of dyad members as one of several predictors of the quality of leader-member exchanges of 49 Junior Achievement Companies ranging from six to 25 members. This longitudinal study measured the quality of exchanges over a six-month period. The first set of measures was 
administered during the groups' fourth weekly meeting to allow for the opportunity to form initial impressions of each other. The second set of measures was administered six months later. Applying a regression equation, the data revealed sex does predict "in-groupness" at Time One but not at Time Two. When the sex of manager and direct report are the same, the relationship was more likely characterized as an "in-group” (high quality LMX) relationship, but only early in the dyad tenure. However, sex did predict "out-groupness" at both Time One and Time Two, suggesting that dyads composed of individuals of differing sex was more likely to be characterized with lower quality of exchanges. They concluded that certain demographic characteristics, such as sex, appear predictive of in- and out-group status over time. Put differently, when the sex of direct reports and managers were different, the relationship was more likely to be characterized as “out-group” (low quality of LMX).

However, other research regarding the predictive nature of the role of demographically similar and demographically different dyads on leader-member exchange is less clear. Examining longitudinal data of the quality of leadermember exchanges, Liden, et al. (1993) assessed newly formed employee dyads (at two weeks, six weeks and six months of the dyadic relationships). The data indicated that demographic similarity and performance rating, relative to expectations, were not significant predictors of LMX at any time period. This is not to say that sex of dyad members alone has no impact on the predictive nature of LMX. Because the researchers operationalized demographic similarity as a composite of sex discrepancy, race discrepancy, education discrepancy, and age discrepancy between manager and direct report, claims for this research are tenuous regarding the affect of sex of dyad members on LMX.

Basu and Green (1995) examined attitudinal similarity and other predictor variables among 223 randomly selected direct reports of 58 first-line supervisors of a Fortune 500 manufacturing plant. Demographic similarity, a composite variable including age, sex, race, education, and organizational tenure, yielded no predictive relationship with leader-member exchange as reported by direct reports. The lack of relationship might be due to the extreme homogeneity of the sample. Approximately $95 \%$ of the sample was Caucasian, $70 \%$ of direct reports and 56 of 58 supervisors were men.

In summary, the relationship of demographic similarity of dyad members has inconsistently predicted LMX. Several studies concluded sex similarity of dyads was a predictor of high quality of exchange. Other research indicated sex dissimilarity of dyads was negatively related to quality of exchange. However, a number of studies yielded inconclusive results regarding the predictive ability of demographic similarity of dyads on quality of exchanges. Further research is required to definitively determine the strength of this predictor. 


\section{Sex Similarities/Differences and LMX}

While there appears to be substantial research investigating the role of demographic similarities on quality leader-member exchanges, few studies have specifically assessed sex of dyad members as a discrete variable from other demographic variables (e.g. Bauer \& Green, 1996; Green, et al., 1996; Murphy \& Ensher, 1999; Pelled \& Xin, 2000; Varma \& Stroh, 2001).

Bauer and Green (1996) also explored a possible direct relationship between sex similarity of dyad members and LMX. At three periods (one week, 12 weeks, and 34 weeks) longitudinal data was collected from 311 graduating students who were entering new jobs after college. In addition to demographic variables, survey data was collected from both direct reports and managers regarding the quality of leader-member exchange relationship as measured by the LMX-7 developed by Scandura and Graen (1984). Data indicated sex similarity of dyad members was not related to "Time 3" leader-member exchange quality after controlling for other predictors. In other words, there was no difference between the quality of exchanges between same sex dyads and different sex dyads. The authors were disappointed in the predictive power of sex similarity of dyad members.

Murphy and Ensher (1999) offered a bit more insight into the role of sex of dyad members in predicting LMX. Their sample consisted of 104 interns who participated in an eight-week summer job training program at a large media organization. In addition to the baseline demographic data collected, both managers and direct reports responded to the LMX-7 scale developed by Scandura and Graen (1984). Through analysis of variance on same- and mixedsex dyads, only one significant relationship was identified: from an intern perspective, female managers were rated as providing higher quality LMX than male managers.

Yet another study yielded conflicting results regarding sex similarity of dyad members. Green, et al. (1996) also examined the role of same-sex and differentsex dyads as predictors on the quality of leader-member exchanges. The study sampled 358 employees among 42 public libraries. Measuring direct report perceptions of leader-member exchange using a seven-item scale (Graen, et al., 1982), they also collected baseline demographic data. Standardized parameter estimates for the theoretical model indicated sex dissimilarity was related to lower quality leader-member exchanges. However, these results are tenuous because the participant sample was overwhelmingly female (female direct reports, 93\%; female managers, 67\%).

An empirical investigation was conducted comparing the role of sex similarity in dyads across cultures (Pelled \& Xin, 2000), specifically comparing samples from the United States and Mexico. Surveys were administered at two production facilities (one in the Midwestern region of the United States and one in northern Mexico). Direct reports responded to the six-item scale developed by Graen, et al. 
(1982) to assess LMX. In addition, participants reported demographic variables such as sex, race, and age. The results within the United States sample indicated there were positive associations between sex similarity of dyads and LMX as well as between race similarity and LMX. Within the Mexican sample, the study also revealed positive associations between sex similarity of dyads and LMX. Unexpectedly sex similarity has a weaker effect on LMX in Mexico than in the United States. Pelled and Xin (2000) offered a possible explanation. They suggested that the LMX construct is largely concerned with support and understanding which are often regarded as feminine (nurturing, behaviors).

In a recent study, Varma and Stroh (2001) examined the impact of sex of dyad members on LMX and performance evaluations. Other studies regarding the impact of sex of dyad members on quality leader-member exchanges only investigated the notion of similar- and mixed-sex dyads. Varma and Stroh (2001), however, examined four dyad combinations with regard to sex of dyad members (female manager and female direct report; female manager and male direct report; male manager and female direct report; and male manager and male direct report). The study made use of Graen's (1976) seven-item measure of LMX and an eightitem scale of performance ratings developed during the study as the principle dependent variables. The results indicated that female managers rated female direct reports significantly higher than male managers of male direct reports. Also, though not statistically significant, female managers rated the performance of female direct reports higher than male managers of male direct reports. Additionally, when examining same-sex and mixed-sex dyads, both quality leader-member exchanges and performance ratings were significantly higher among same-sex dyads than were reported among mixed-sex dyads.

\section{Other Relevant Research Examining Same- and Mixed-Sex Dyads}

A body of research has informed propositions and hypotheses regarding the notion of sex of dyad member effects on the development of LMX. This area of research examines the effects of sex of dyad members and other simple demographic variables on performance appraisals (Mobley, 1982), liking, role ambiguity, and role conflict (Tsui \& O’Reilly, 1989) within manager-direct report dyads.

Mobley (1982) investigated the role of sex of dyad members and race effects on managers' performance evaluations of direct reports. Speculating that on average females would be rated less favorably than males, and raters would give the highest evaluations to members of their own sex, the study examined survey data collected from members of a large supply distribution center located in the eastern part of the United States. The test for main effects of sex of dyad members did not support the notion that males would be rated higher than females. Rather, the data indicated that females were rated significantly higher than males. Moreover, the tests for main effects and interactions indicated that raters evaluated their own subgroup (sex and race) higher than other subgroups (sex and race). 
Tsui and O’Reilly (1989) also examined the effect of demographic variables as predictors of manager's performance ratings, liking for direct reports, role ambiguity and role conflict. This study was similar to Mobley’s (1982) study examining demographic characteristics, however, it investigated same- and mixed-sex dyads. Survey data of middle managers and their superiors in a Fortune 500 multidivisional corporation yielded 272 manager-direct report dyads. The data indicated direct reports in mixed-sex dyads were rated as performing more poorly and were liked less than direct reports of same-sex dyads. In addition, direct reports of mixed-sex dyads reported greater role conflict and role ambiguity than direct reports of same-sex dyads. Moreover, data indicated women direct reports of women managers reported the lowest levels of role ambiguity; they were rated to be the higher performers; and, they were liked most by their managers. The findings in this study regarding sex similarity among managerdirect report dyads yielded results inconsistent with Mobley (1982).

This area of research examining the effects of sex of dyad members on variables such as performance ratings or liking of the direct report does not directly investigate the role of sex of dyad members and LMX. However, studies such as these support the notion that sex of dyad members may affect individuals' perceptions of other participants among dyadic relationships. At a minimum, these results are inconclusive in determining if a sex-bias effect exists. Certainly, further research is required to confirm or disconfirm the potential effects.

\section{Discussion}

\section{Implications for Research}

In summary, the current research has yielded inconsistent results with regard to the role of sex of dyad members and the development of LMX. It is still unclear how sex of dyad members impacts LMX. Research examining demographic similarities and sex similarities among dyad members has yielded, at best, inconclusive results. Further research is needed to support or disprove the theorized notions of same- and mixed-sex dyads. There are encouraging avenues for researchers interested in leader-member exchange and gender. This section seeks to explore several possible opportunities future researchers may endeavor to address.

One avenue of research should investigate the nature of the LMX. For instance, Dienesch and Liden (1989) indicated that the LMX construct may not be a one dimensional construct as commonly accepted. Rather, they indicated that leadermember exchange is composed of four dimensions (affect, loyalty, contribution, and professional respect). Unfortunately, to date few published studies have approached quality leader-member exchanges with this multi-dimensional perspective (e.g., Liden \& Maslyn, 1998; Maslyn \& Uhl-Bien, 2001). Does sex of 
dyad members affect one or all of these dimensions of LMX quality? This question needs to be addressed by further research.

To date limited research has been conducted examining sex bias in the development of quality leader-member exchanges. Only Varma and Stroh (2001) actually compared all biological sex combinations in dyadic structure offering a more precise examination of the role of sex of dyad members than other research which simply compares same-sex and mixed-sex dyad combinations. Yet, further research is required to specify effects beyond the notions of sex biases in the performance appraisal process. Future research must include other samples, beyond production floor employees and communication industry employees, to determine if previous studies have yielded generalizable data. Additionally, samples must be composed of demographically balanced and diverse participants to yield more conclusive results.

Numerous empirical studies examined the role of demographic similarity predicting the LMX. Further research is required to understand the impact of demographic, and perhaps situational, variables. The aggregated variable, demographic similarity, often includes age, education level, sex, company tenure, and job tenure. A logical next step in research should examine the variance explained by each of these sub-variables in potential interactive effects of situational variables such as unit size, workload, and available resources (Green, et al., 1996).

In addition to further research regarding the role of sex of dyad members on the quality of leader-member exchanges, research should examine the impact of social role theory on the development of quality leader-member exchanges. Wayne, et al. (1994) postulated the effects of LMX on women holding traditionally masculine or neutral positions. However, the potential effects of social roles (e.g., feminine, masculine or neutral) remain unexamined. Feminine social roles generally refer to communal characteristics which facilitate nurturing behaviors, particularly "superior interpersonal skills and ability to communicate nonverbally” (Eagly, Wood, \& Diekman, 2000, p. 126). Conversely, masculine social roles refer to agentic characteristics which favor a pattern of assertive and independent behaviors. Examination of social role theory may well explain variance above and beyond simple biological sex differences and similarities among dyad members.

Social roles and biological sex differences may impact the accumulation of social capital, which in turn, may contribute to the development and enhancement of the quality leader-member exchanges. Social capital generally refers to relationships as a resource for social action (Nahapiet \& Ghoshal, 1998). Put differently, social capital is "the making use of relationships for personal and/or organizational benefit.” Nahapiet and Ghoshal theorized social capital is comprised of three dimensions: structural, cognitive, and relational dimensions. Perhaps LMX theory explains to a large extent the relational dimension of social capital. 
LMX research often examines the quality of relationships at the dyadic level. However, social capital refers to quality of linkages from an organizational level of analysis. The opportunity remains for leader-member exchange theory to inform social capital scholars based on the aggregated dyads within organizations. Graen and Uhl-Bien (1995) called for a similar evolution of LMX theory. They asserted network assemblies, a system of interdependent dyadic relationships, constitute the leadership structure within organizations. Even now, this systems perspective LMX research remains unexamined. Further conceptualization and theory development is required to establish empirically based linkages between LMX and other organizational behavior constructs.

\section{Implications for Practice}

On the practitioner side, research regarding the effect of sex of dyad members on LMX quality informs our understanding of potential relationship problems between managers and direct reports. These insights may help direct managers' efforts to more effectively spend time and energy cultivating and enhancing the quality of exchanges with direct reports.

Women are more likely than men to be employed in positions of relatively low status (e.g., Federal Glass Ceiling Commission, 1995). Further, women are "much scarcer" than men at higher levels of organizations. Future research regarding sex, and perhaps social roles, on the development of quality leader-member exchanges may offer new insight in creating a more equitable balance in the promotion of women toward higher positions. Fostering high quality leader-member exchanges may be one means by which organizations may intentionally create the social capital necessary for women to advance through the organizational structure.

Furthermore, this research may inform human resource managers to help in focusing efforts toward developing quality leader-member exchanges among organization members. Likewise, the dimensions of quality LMX could further assist in creating awareness of the nature of quality exchanges. For instance, organizations commonly use mentoring programs to offer new employees the opportunity for personalized attention to assist them in becoming acculturated to the organization or to help them develop particular knowledge and skills to become more effective within the organization. Understanding gained from further research regarding the impact on the quality of exchange relationships may inform human resource managers thereby creating more successful mentoring partnerships.

\section{References}

Basu, R. (1991). An empirical examination of LMX and transformational leadership as predictors of innovative behavior. UMI Dissertation Services. Ann Arbor, MI: University Microfilms International, 9201299. 
Basu, R., \& Green, S. G. (1995). Subordinate performance, leader-subordinate compatibility, and exchange quality in leader-member dyads: A field study. Journal of Applied Social Psychology, 25(1), 77-92.

Bauer, T. N., \& Green, S. G. (1996). Development of leader-member exchange: A longitudinal test. Academy of Management Journal, 39(6), 1538-1567.

Dansereau, F., Jr., Graen, G., \& Haga, W. J. (1975). A vertical dyad linkage approach to leadership within formal organizations: A longitudinal investigation of the role-making process. Organizational Behavior and Human Performance, 13, 46-78.

Dienesch, R. M., \& Liden, R. C. (1989). Leader-member exchange model of leadership: A critique and further development. Academy of Management Review, 11(3), 618-634.

Duchon, D., Green, S. G., \& Taber, T. D. (1986). Vertical dyad linkage: A longitudinal assessment of antecedents, measures and consequences. Journal of Applied Psychology, 71(1), 56-60.

Eagly, A. H., Wood, W., \& Diekman, A. B. (2000). Social role theory of sex differences and similarities: A current appraisal. In T. Eckes, \& H. M. Trautner (Eds). The developmental social psychology of gender (pp. 123-174). Mahwah, NJ: Lawrence Erlbaum Associates

Federal Glass Ceiling Commission. (1995). Good for business: Making full use of the nation's human capital: The environmental scan: A fact-finding report of the Federal Glass Ceiling Commission. Washington, DC: Glass Ceiling Commission, U.S. Department of Labor.

Gerstner, C. R., \& Day, D. V. (1997). Meta-analytic review of leader-member exchange theory: Correlates and construct issues. Journal of Applied Psychology, 82(6), 827-844.

Graen, G. (1976). Role making processes within complex organizations. In M. D. Dunnette (Ed.), Handbook of industrial and organizational psychology (pp. 12011245). Chicago: Rand McNally.

Graen, G., Dansereau, F., Jr., \& Minami, T. (1972). An empirical test of the manin-the-middle hypothesis among executives in a hierarchical organization employing a unit-set analysis. Organizational Behavior and Human Performance, 8, 262-285.

Graen, G., Novak, M. A., \& Sommerkamp, P. (1982). The effects of leadermember exchange and job design on productivity and job satisfaction: Testing a 
dual attachment model. Organizational Behavior and Human Performance, 30, 109-131.

Graen, G., Orris, J. B., \& Johnson, T. W. (1973). Role assimilation processes in a complex organization. Journal of Vocational Behavior, 3, 395-420.

Graen, G., \& Schiemann, W. (1978). Leader-member agreement: A vertical dyad linkage approach. Journal of Applied Psychology, 63, 206-212.

Graen, G. B., \& Uhl-Bien, M. (1991). The transformation of professionals into self-managing and partially self-designing contributors: Toward a theory of leadership-making. Journal of Management Systems, 3, 25-39.

Graen, G. B., \& Uhl-Bien, M. (1995). Relationship-based approach to leadership: Development of leader-member exchanges (LMX) theory of leadership over 25 years: Applying a multi-level multi-domain perspective. Leadership Quarterly, 6, 219-247.

Green, S. G., Anderson, S. E., \& Shivers, S. L. (1996). Demographic and organizational influences on leader-member exchange and related work attitudes. Organizational Behavior and Human Decision Processes, 66(2), 203-214.

Heneman, R. L., Greenberger, D. B., \& Anonyuo, C. (1989). Attributes and exchanges: The effects of interpersonal factors on the diagnosis of employee performance. Academy of Management Journal, 32, 466-476.

Hui, C., Law, K. S., \& Chen, Z. X. (1999). A structural equation model of the effects of negative affectivity, leader-member exchange, and perceived job mobility on in-role and extra-role performance: A Chinese case. Organizational Behavior and Human Decision Processes, 77(1), 3-21.

Kinicki, A. J., \& Vecchio, R. P. (1994). Influences on the quality of supervisorsubordinate relations: The role of time-pressure, organizational commitment, and locus of control. Journal of Organizational Behavior, 15, 75-82.

Larwood, L., \& Blackmore, J. (1978). Sex discrimination in managerial selection: Testing predictions of the vertical dyad linkage model. Sex Roles, 4(3), 359-367.

Liden, R. C., \& Maslyn, J. M. (1998). Multidimensionality of leader-member exchange: An empirical assessment through scale development. Journal of Management, 24(1), 43-72.

Liden, R. C., Wayne, S. J., \& Stilwell, D. (1993). A longitudinal study on the early development of leader-member exchanges. Journal of Applied Psychology, 78(4), 662-674. 
Maslyn, J. M., \& Uhl-Bien, M. (2001). Leader-member exchange and its dimensions: Effects of self-effort and other's effort on relationship quality. Journal of Applied Psychology, 86(4), 697-708.

Mobley, W. H. (1982). Supervisor and employee race and sex effects on performance appraisals: A field study of adverse impact and generalizability. Academy of Management Journal, 25(3), 598-606.

Murphy, S. E., \& Ensher, E. A. (1999). The effects of leader and subordinate characteristics in the development of leader-member exchange quality. Journal of Applied Social Psychology, 29(7), 1371-1394.

Nahapiet, J., \& Ghoshal, S. (1998). Social capital, intellectual capital, and the organizational advantage. Academy of Management Review, 23(2), 242-266.

Pelled, L. H., \& Xin, K. R. (2000). Relational demography and relationship quality in two cultures. Organization Studies, 21(6), 1077-1094.

Phillips, R. L., \& Bedeian, A. G. (1994). Leader-follower exchange quality: The role of personal and interpersonal attributes. Academy of Management Journal, 37, 990-1001.

Scandura, T. A., \& Graen, G. B. (1984). Moderating effects of initial leadermember exchange status on the effects of a leadership intervention. Journal of Applied Psychology, 69, 428-436.

Scandura, T. A., Graen, G. B., \& Novak, M. A. (1986). When managers decide not to decide autocratically: An investigation of leader-member exchange and decision influence. Journal of Applied Psychology, 71, 579-584.

Schiemann, W. A., \& Graen, G. B. (1984). Structural and interpersonal effects in patterns of managerial communication. Unpublished manuscript, Department of Management, University of Cincinnati.

Schriesheim, C. A., Castro, S. L., \& Cogliser, C. C. (1999). Leader-member exchange (LMX) research: A comprehensive review of theory, measurement, and data-analytic practices. Leadership Quarterly, 10(1), 63-113.

Seers, A., \& Graen, G. B. (1984). The dual attachment concept: A longitudinal investigation of the combination of task characteristics and leader-member exchange. Organizational Behavior and Human Performance, 33, 283-306.

Tsui, A. S., \& O’Reilly, C. A. (1989). Beyond simple demographic effects: The importance of relational demography in superior-subordinate dyads. Academy of Management Journal, 32(2), 402-423. 
Varma, A., \& Stroh, L. K. (2001). The impact of same-sex LMX dyads on performance evaluations. Human Resource Management, 40(4), 309-320.

Vecchio, R. P., \& Gobdel, B. C. (1984). The vertical dyad linkage model of leadership: Problems and perspectives. Organizational Behavior and Human Performance, 34, 5-20.

Wayne, S. J., Liden, R. C., \& Sparrowe, R. T. (1994). Developing Leadermember exchanges: The influence of gender and ingratiation. American Behavioral Scientist, 37(5), 697-714. 